\title{
MANAJEMEN BISNIS SYARIAH SEBAGAI UPAYA MERAIH RIZKI YANG BERKAH: SEBUAH ARTIKEL ULAS BALIK
}

\author{
Oleh: \\ Karsidi ${ }^{1)}$ \\ Bambang Sunarko ${ }^{2)}$ \\ Ashari ${ }^{3)}$ \\ Email: deboragracia93@gmail.com \\ 1) 2) 3) Dosen Fakultas Ekonomi \& Bisnis, Universitas Ma Chung
}

\begin{abstract}
Islam teaches and recommends us to do all the things in the life seriously and orderly based on the norms established by the religion. Management means to regulate all the things in order to be well done, precise, in good order, and complete. This activity is declared in Islamic Doctrines. Therefore, if a business is carried out by the guidance of the norms of the Declared-Islamic Doctriness, the business will not only persue the material benefits, but also will hope the Favor and the Bless of Alloh/God. The business that is carried out based on the law of Islam is then termed by the Syariah Business Management. The material benefit gained from this business will have favor of Alloh/God and has the grant of Alloh/God in it.
\end{abstract}

Keywords: management, business, the law of Islam

\section{PENDAHULUAN}

Sudah sejak zaman Rosululloh Muhammad SAW, umat Islam berkecimpung di dalam dunia bisnis bersama-sama dengan baginda Rosul dan mencapai keberhasilan secara materi maupun keberhasilan meraih ridho Illahi.

Dalam tarikh Islam tidak sedikit dikisahkan adanya para shahabat Rosululloh SAW yang menjadi pedagang maupun pengusaha besar dan berhasil mengembangkan jaringan bisnisnya menembus batas territorial Makkah dan Madinah. Dengan berdasar pada ajaran ekonomi syariah dan di bawah bimbingan Rosululloh SAW, mereka giat membangun kehidupan bisnisnya demi kesejahteraan umat. Tidak terbatas dalam hal transaksi perdagangan, namun dalam hal manajemen bisnis pun mereka teguh berpedoman pada nilai-nilai atau norma-norma keislaman termasuk dalam hal pengambilan keputusan bisnisnya.

Waktu terus bergulir, perkembangan ilmu dan teknologi terus maju, persaingan dalam kehidupan umat manusia dalam berbagai bidang terus berlangsung, kebutuhan hidup manusia semakin beragam, semakin banyak hal yang menuntut untuk dapat dipenuhi. Dalam situasi dan kondisi seperti itulah, manakala seseorang manusia jiwanya lebih dikuasai oleh hawa nafsu, jauh dari nilai-nilai atau norma-norma agama (Islam) kemudian juga dibarengi dengan adanya pengaruh system ekonomi sekuler dari Barat, maka umat Islam disadari atau tanpa disadari, cepat atau lambat sedikit demi sedikit bergeser meninggalkan 
dan menanggalkan syariat Islam di dalam perilaku bisnis mereka dan itu masih terasa dan terlihat nyata di masyarakat kita (Muslim) di Indonesia hingga sekarang.(Muhammad Ismail Yusanto, 2002)

Maka sudah barang tentu, situasi dan kondisi seperti itu adalah menjadi tugas dan tanggung jawab setiap muslim untuk mengendalikan dan mengembalikan ruh Islam ke dalam jiwa umat Islam terutama para pelaku bisnis, para pengusaha, para ekonom dan lain sebagainya dengan sekuat tenaga dan kemampuannya untuk berbisnis dengan menerapkan manajemen yang syar'i guna meraih ridho Illahi.

\section{PEMBAHASAN}

Dalam pandangan ajaran Islam, segala sesuatu dalam hidup dan kehidupan ini harus dilakukan secara rapi, tertata, terrencana, tertib, benar dengan mengikuti kaidah-kaidah yang dapat dipercaya dandapat dipertanggungjawabkan kebenarannya. Segala hal tidak boleh dilakukan dengan asal-asalan, dalam hal ini semua harus dilakukan secara sungguh-sungguh dan patuh terhadap kaidah-kaidah syariah, dan itulah merupakan prinsip utama dalam ajaran Islam.

Rosululloh Saw telah bersabda dalam sebuah hadits yang terjemahnya sebagai berikut:

"Sesungguhnya Alloh sangat mencintai orang yang jika melakukan sesuatu pekerjaan, dilakukan secara itqon(tepat, terarah, jelas dan tuntas). (HR. Thobroni)

Adanya arah suatu pekerjaan yang jelas, landasan yang mantap, dan cara mendapatkannya juga transparan, adalah merupakan amal (perbuatan) yang dicintai dan diridloi Alloh Swt. Sebenarnya, "manajemen" dalam arti mengatur segala sesuatu agar dilakukan dengan baik, tepat, teratur dan tuntas adalah merupakan hal yang disyariatkan dalam ajaran Islam.

Proses-proses manajemen pada dasarnya adalah perencanaan dari segala sesuatu secara mantap untuk melahirkan keyakinan yang berdampak pada melakukan sesuatu sesuai dengan aturan serta memiliki manfaat. Maka, perbuatan yang tidak ada manfaatnya adalah bisa dikatakan sebagai perbuatan yang tidak pernah direncanakan. Jika perbuatan itu tidak pernah direncanakan, maka hal yang seperti itu tidak termasuk dalam kategori manajemen yang baik, dan sesuatu yang tidak baik jelas berada di luar area ajaran Islam.

Kemudian menyangkut dalam hal bisnis yang juga terus berkembang sejalan dengan perkembangan ilmu-ilmu kemakmuran inderawi yang jumlahnya semakin lama semakin bertambah banyak. Oleh karena itu, peningkatan kemampuan untuk lebih kompetitif dalam memutar roda bisnis mutlak diperlukan agar manusia mampu mempertahankan keberlangsungan usahanya dalam situasi kompetisi yang semakin ketat.

Dalam kondisi yang seperti itu, tidak jarang semata-mata demi mencari keuntungan, banyak yang tanpa berpikir panjang nekat menggunakan segala macam cara yang jelas-jelas batil (tidak syar'i), jiwanya jauh dari ajaran Alloh Swt yang pada gilirannya keuntungan (harta) yang diperolehnya pun tidak mendapat berkah yang cepat atau lambat menuju kehancuran.

Ilmu bisnis syariah adalah ilmu yang mengajarkan cara-cara berbisnis yang berkah dan kesuksesan di dunia sebagai ibadah untuk menyongsong kesuksesan akhirat dengan meraih balasan dari Alloh Swt yang luar biasa yaitu surga. Namun sayangnya banyak para pelaku bisnis (pengusaha) yang mengaku muslim masih belum mau menempatkan dan atau menggunakan ilmu bisnis syariah sebagai primadona dalam realitas bisnis mereka.

Kegiatan bisnis menurut Islam, tidak bisa diatur hanya dengan teori, akal, keinginan dan pengalaman manusia semata, akan tetapi kegiatan bisnis itu juga harus melibatkan keselarasan hati dan ketakwaan atas dasar iman yang benar kepada Alloh Swt Tuhan Penguasa alam semesta.

Ketika bisnis sebagai salah satu usaha mencari rizki dibangun dan dilaksanakan dengan konsep mencari kesejahteraan 
hidup di dunia yang berkah sekaligus mempersiapkan kebahagiaan yang hakiki di akhirat nanti atas dasar iman, takwa, tawakal, jujur dan senantiasa memelihra diri dari segala hal yang dibenci oleh Alloh Swt di saat itulah Alloh Swt memberikan kemudahan-kemudahan untuk mendapatkan rizki yang halalan thoyiban (rizki yang baik dan halal) dengan tidak kemudian lupa untuk mensyukurinya, mengeluarkan zakat, infak dan shodakoh. Insya Alloh itulah kategori kegiatan bisnis yang berkah yang selalu berjalan di atas rel syariah (Ali Hasan, 2009).

Di dalam ajaran agama Islam dikenal bahwa " syariah " adalah sebagai "God's Laws" atau "Islamic Laws" yang mengatur persoalan ibadah dan juga muamalah. Syariah adalah seperangkat " $d o$ 's and don'ts" mengatur yang diperbolehkan dan yang dilarang. Tujuan syariah yang paling utama adalah memajukan kesejahteraan manusia yang terletak pada jaminan atas keyakinan, intelektual, harta dan masa depannya.

Kebutuhan terhadap harta (kekayaan) adalah wajar karena untuk menopang pelaksanaan perintah-perintah Alloh Swt jel as membutuhkan harta (kekayaan) tersebut. Banyak contoh berbagai perintah Alloh Swt yang memerlukan harta misalnya: untuk bisa melaksanakan ibadah sholat jelas perlu berpakaian, dan untuk mendapatkan pakaian itu jelas harus beli, untuk bisan beli pakaian harus punya uang (harta sebagai alat pembayaran dalam jual-beli). Untuk bisa melaksanakan ibadah haji (lebih-lebih) jelas dibutuhkan kemampuan finansial (harta) yang cukup karena ibadah haji memang ibadah yang harus didukung adanya kemampuan keuangan (harta) yang memadai. Untuk dapat memiliki kemampuan di bidang keuangan (harta), salah satunya adalah dengan berbisnis.

Dalam kamus Bahasa Indonesia, bisnis diartikan sebagai usaha dagang, usaha komersial di dunia perdagangan, dan bidang usaha. (Suharto,1989) Menurut pendapat Skinner (1992) mendefinisikan bahwa bisnis adalah sebagai pertukaran barang, jasa, atau uang yang saling menguntngkan atau memberi manfaat. Adapun menurut pandangan Straub dan Attner (1994), bisnis itu tak lain adalah suatu organisasi yang menjalankan aktifitas produksi dan penjualan barang-barang dan jasa-jasa yang diinginkan oleh konsumen untuk memperoleh profit. Barang adalah suatu produk yang secara fisik memiliki wujud (dapat diindra), sedangkan jasa adalah aktifitas-aktifitas yang memberi manfaat kepada konsumen atau para pelaku bisnis lainnya.

Kemudian apa yang dimaksud dengan "bisnis islami" atau selanjutnya lebih familier disebut dengan "bisnis syariah"?

Bisnis islami (bisnis syariah) dapat didefinisikan sebagai seangkaian aktifitas bisnis dalam berbagai jenis atau bentuknya yang tidak dibatasi jumlah (kuantitas) kepemilikan hartanya (barang/jasa) termasuk profitnya, namun dibatasi (diatur) dalam cara perolehan dan pendayagunaan harta tersebut, dalam arti ada aturan halal \& haramnya. (M.Ismail Y, 2002)

Oleh karena itu, dengan kendali syariat Islam kegiatan bisnis pada dasarnya untuk mencapai adanya empat hal utama, yaitu:

1. Target hasil: profit materi dan benefit non materi. Tujuan perusahaan (bisnis) harus tidak hanya untuk mencari profit (qimah madiyahi atau nilai materi) setinggi-tingginya, akan tetapi juga harus dapat memperoleh dan memberikan benefit (keuntngan atau manfaat) non materi kepada internal organisasi perusahaan maupun eksternal (lingkungan sekitar) seperti terciptanya suasana persaudaraan, ketentraman lingkungan, kepedulian sosial dan sebagainya.

2. Pertumbuhan: jika profit materi dan benefit non materi telah diraih sesuai dengan target, perusahaan (kegiatan bisnis) tersebut akan mengupayakan pertumbuhan atau kenaikan terusmenerus dari setiap profit dan benefitnya itu. Sudah barang tentu penumbuhan usaha (bisnis) tersebut tetap dijalankan dalam koridor syariat Islam. 
3. Keberlangsungan: belum dapat dikatakan sempurna orientasi manajemen perusahaan (bisnis) apabila hanya berhenti sebatas pada pencapaian target hasil dan pertumbuhan. Oleh sebab itu, perlu terus diupayakan agar pertumbuhan target hasil yang telah diraih dapat dijaga keberlangsungannya dalam kurun waktu yang selama mungkin. Sebagaimana upaya pertumbuhan, setiap aktifitas untuk menjaga keberlangsungan ini juga harus dijalankan dalam batas (koridor) syariah.

4. Keberkahan: factor keberkahan atau adanya orientasi untuk menggapai keridhoan Alloh Swt merupakan puncak kebahagiaan hidup manusia muslim. Apabila hal in tercapai, menandakan terpenuhinya dua syarat diterimanya amal manusia, yaitu adanya elemen niat ikhlas dan cara yang sesuai dengan tuntunan syariat.

Sebagai contoh konkrit dalam hal bisnis adalah al-bai' (jual-beli). Jual-beli menurut bahasa adalah: menerima atau menyerahkan suatu barang dengan barang lain dalam bentuk akad. Sedang menurut syara', al-bai' (jual-beli) adalah menerima uang dari hasil penjualan barang atau jasa berdasarkan aturan syariat.(Marzuqi Yahya,2012) Pengertian jual-beli yang senada terdapat dalam buku Fiqh Islam bahwa: jual-beli adalah menukar suatu barang dengan barang yang lain dengan cara (akad) yang tertentu.(Sulaiman Rasyid, 2013)

Adapun disyariatkannya jual-beli di dalam ajaran Islam adalah: Mengantarkan manusia kepada pencapaian / pemenuhan kebutuhannya tentang sesuatu yang ada di tangan saudaranya tanpa adanya kesulitan dan madhorot apapun.(Syaikh Abu Bakar Jabir, 2012)

Agar dalam kegiatan perniagaan (bisnis) yang dalam hal ini adalah al-bai' (jual-beli) itu mendapatkan ridho dan berkah dari Alloh Swt, maka para pelakunya (baik pihak penjual maupun pembeli) harus mematuhi ketentuan-ketentuan aturan main yang bisa dan biasa disebut "manajemen bisnis syariah" artinya di dalam kegiatan transaksi jual-beli harus mengikuti dan atau memenuhi syarat \& rukun yang telah ditentukan di dalam syariat agama Islam.

Sebelum mengupas tentang syarat, kita dahulukan mengenai rukun (hal-hal yang harus ada) di dalam jual-beli.

Mengenai rukun jual-beli menurut syariat Islam ada 5 (lima) macam, yaitu:

1. Penjual, yaitu orang yang secara sah memiliki barang (sesuatu yang berharga) yang akan dijual-belikan atau bisa juga orang lain (bukan pemilik sah) yang mendapat mandat atau kepercayaan penuh dari pemilik sah barang yang akan dijual-belikan yang bisa dibuktikan (misal: ada surat kuasa untuk menjual)

2. Pembeli, yaitu orang yang memang berminat dan berniat ingin memiliki barang yang akan dijual-belikan tersebut dengan cara yang telah ditentukan dalam transaksi jual-beli menurut ajaran agama Islam.

3. Barang yang akan dijual, yaitu barang yang berharga dan memang secara umum bisa dan biasa diperjual-belikan atau dibutuhkan oleh masyarakat luas.

4. Akad, yaitu adanya kalimat ijab dan qabul antara pihak penjual dan pembeli yang merupakan kesepakatan keduanya di dalam transaksi jual-beli.

5. Keridhoan, yaitu kerelaan hati antara pihak penjual dan pembeli atas terjadinya transaksi jual-beli tersebut. Artinya kedua belah pihak benar-benar tidak ada unsur keterpaksaan dari pihak manapun berkait dengan transaksi jualbeli yang mereka lakukan. Hal ini berdasar pada firman Alloh Swt di dalam Al-Qur'an surat An-Nisa, ayat 29 yang terjemahnya: “ Janganlah kamu sekalian saling memakan harta sesamamu dengan jalan yang batil, kecuali dengan jalan perniagaan (jual-beli) yang dil- 
akukan secara suka sama suka di antara kamu”. (Syaikh Abu Bakar Jabir, 2012)

Selanjutnya setelah rukun di dalam jual-beli tersebut terpenuhi, maka agar memperoleh ridho (berkah) dari Alloh Swt transaksi jual-beli tersebut juga harus memenuhi syarat yang juga telah ditentukan di dalam ajaran agama Islam.

Adapun syarat-syarat yang dimaksud adalah sebagai berikut:

1. Penjual dan pembeli, syaratnya adalah:

a. Berakal sehat, artinya keduanya adalah bukan orang yang bodoh dan juga bukan orang gila.

b. Dengan kehendak sendiri, artinya keduanya di dalam melakukan transaksi jual-beli tersebut sama sekali tidak ada tekanan atau paksaan dari pihak manapun atau dengan kata lain dilakukan secara suka rela di antara kedua belah pihak.

c. Dewasa, artinya keduanya telah baligh (baligh=sampai) maksudnya kedua belah pihak sudah sampai pada batas umur dewasa, bukan anak-anak lagi. Adapun anak-anak yang sudah nalar (mengerti) tentang transaksi jual-beli, menurut sebagian ulama bahwa anak-anak diperbolehkan bertransaksi jual-beli terhadap barang-barang yang nilai harganya kecil. Karena jika tidak diperbolehkan, sudah tentu menjadikan suatu kesulitan, sedangkan agama Islam sekali-kali tidak akan menetapkan suatu peraturan yang mendatangkan kesulitan bagi para pemeluknya.

d. Tidak bersifat pemboros, artinya baik pihak penjual maupun pembeli adalah bukan orang-orang yang punya sifat suka berfoya-foya, menghambur-hamburkan uang atau harta. Sebab bagaimanapun kita semua menyadari tentang bagaimana akibat dari ulah mereka yang suka melakukan pemborosan tentu ujung-ujungnya adalah kesengsaraan bukan kesejahteraan dan kita semua tentu tahu bahwa ajaran Islam tidak akan menjerumuskan manusia ke lembah kesengsaraan.

2. Uang dan barang yang dibeli, syaratnya adalah:

a. Suci, artinya barang yang diperjualbelikan harus barang yang suci, dengan kata lain barang najis tidak sah (tidak boleh) diperjual-belikan seperti kulit binatang yang belum disamak.

b. Ada manfaatnya, artinya barang yang diperjual-belikan itu bermanfaat untuk keperluan pemenuhan kebutuhan di dalam hajat hidup manusia.

c. Dapat diserah-terimakan, artinya barang yang dijual itu setelah terjadi transaksi bisa dengan segera diserahkan kepada yang berhak untuk menerimanya yaitu pembeli. Dengan kata lain, barang yang diperjual-belikan ternyata tidak bisa segera diserahkan kepada pembeli dinyatakan tidak sah menurut syariat Islam, misalnya: menjual ikan yang masih di dalam kolam yang belum bisa diketahui kondisinya, timbangannya dan lain-lain.

d. Barang tersebut milik sah pihak penjual, artinya bukan barang milik orang lain kecuali dia mendapat mandat atau amanat dengan menunjukkan bukti mandat (biasanya berupa surat kuasa) untuk menjualkan. Sehingga barang curian, jelas tidak sah untuk diperjual-belikan dan kalau itu dilakukan cepat atau lambat akan menemui kesulitan di kemudian hari, misalnya jual-beli sepeda motor hasil curian yang tidak ada kelengkapan surat-suratnya.

3. Kalimat ijab dan qobul. Yang dimaksud kalimat ijab dan qobul adalah kata-kata ikrar yang diucapkan oleh pihak penjual 
maupun pembeli pada saat transaksi. Misalnya ijab dengan kalimat " Saya jual barang ini dengan sekian ". Qobul dengan kalimat " Saya beli barang ini dengan menawar sekian ". (Sulaiman Rasjid, 2013)

Ketentuan-ketentuan tersebut di atas (terutama dalam transaksi jual-beli) apabila para pelaku bisnis dengan penuh kesadaran, dilandasi dengan pengetahuan manjemen bisnis yang sesuai dengan syariat agama Islam, bisa dipastikan kegiatan bisnisnya merupakan ibadah, hasil bisnisnya mengandung berkah, sehingga kebahagiaan dan kesejahteraan hidup baik di dunia maupun di akhirat jelas dikaruniakan Alloh Swt sebagai hadiah. Insya Alloh, Allohuma Aamiin Ya Robbal 'alamiin.

\section{KESIMPULAN}

Berdasar pada uraian pendahuluan maupun pembahasan di atas, maka bisa disimpulkan antara lain, bahwa:

1. Agama Islam mengajarkan dan menganjurkan agar segala sesuatu dalam hidup dan kehidupan kita ini bisa dijalani dengan tertib, rapi, teratur dan terrencana sesuai dengan kaidah-kaidah dalam ajaran agama termasuk dalam kegiatan bisnis.

2. Manajemen dalam arti mengatur segala sesuatu agar dapat dilakukan dengan baik, tepat, teratur \& tuntas adalah merupakan hal yang disyariatkan di dalam agama Islam.

3. Manajemen yang baik adalah ditandai dengan adanya suatu rencana yang matang, dan kemudian dilaksanakan dengan tertib dan tuntas sesuai dengan rencana dan tidak menyimpang dari aturan yang telah ditentukan.

4. Kegiatan bisnis syariah adalah kegiatan bisnis yang mengikuti syariat Islam, yang kalau dilakukan hal itu merupakan ibadah yang menghasilkan kesejahteraan hidup di dunia yang berkah dan Alloh Swt memberikan imbalan surga sebagai hadiah.
5. Manajemen bisnis syariah adalah seperangkat aturan yang mengatur tentang hal-hal yang diperbolehkan dan dilarang di dalam ber-muamalah, yang tujuan utamanya adalah memajukan dan meningkatkan kesejahteraan hidup umat manusia.

6. Bisnis syariah adalah bisnis yang islami, artinya kegiatan bisnis yang dilakukan sesuai dengan syariat (hukum) Islam yang tidak membatasi kuantitas (banyaknya) kepemilikan kekayaan (harta) nya, tetapi membatasi (mengatur) dalam hal cara memperoleh maupun menggunakan kekayaan (harta) tersebut.

7. Bisnis syariah diberlakukan pada dasarnya untuk menuju tercapainya 4 (empat) hal utama yaitu: target hasil, pertumbuhan, keberlangsungan, dan keberkahan.

Wallohu a'lam bish-showab dan semoga bermanfaat.

\section{DAFTAR PUSTAKA}

Hafidhuddin,KH.Didin dan Tanjung, Hendri. 2003. Manajemen Syariah dalam Praktik. Jakarta: Gema Insani.

Hasan, Ali. 2009. Manajemen Bisnis Syariah (Kaya di Dunia Terhormat di Akhirat). Yogyakarta: Pustaka Pelajar.

Jabir al-Jaza'iri, Syaikh Abu Bakar. 2012. Minhajul Muslim (Konsep Hidup Ideal dalam Islam) Jakarta: Darul Haq.

Rasjid, Sulaiman. 2013. Fiqh Islam (Hukum Fiqh Lengkap). Bandung: Sinar Baru Algensindo.

Sa'dullah. 2011. Kumpulan Dalil-Dalil AlQur'an dan Hadts. Yogyakarta: Cakrawala.

Suharto dan Iryanto, Tata. 1989. Kamus Bahasa Indonesia. Surabaya: Indah. 
Yahya, Marzuqi. Tanpa Tahun. Panduan Fiih Imam Syafi'i. Jakarta: Al-Maghfiroh.
Yusanto, M. Ismail dan Wijayakusuma, M. Karebet. 2002. Menggagas Bisnis Islami. Jakarta: Gema Insani.

Qardawi, Yusuf. 1997. Norma dan Etika Ekonomi Islam. Jakarta: Gema Insan 